\title{
SOME ANTS FROM THE BAHAMA ISLANDS
}

\author{
By William MORTON WHEeler \\ Biological Laboratories, Harvard University
}

Our knowledge of insect distribution in the Bahamas is very meager, limited as it is to a very few of the nearly seven hundred islands and cays composing the archipelago. Of the ants, a group of greater importance in zoögeographical discussion than many other families or even orders less intimately dependent on the soil, I have records from only three of the islands. The account of these insects which I published nearly 30 years ago ${ }^{1}$ was based on material which I collected on New Providence and Andros. Mann, 1920, in addition to recording and describing several new forms from the same localities, cited seven species collected by Bluff on Eleuthera Island ${ }^{2}$. I was glad, therefore, to receive from Dr. David Fairchild and Mr. James Greenway a collection of ants which they made on New Providence Island and on some thirteen of the other islands while they were collecting plants, birds and mammals on two expeditions, during 1932 and 1933, of Mr. Allison Armour's yacht, the "Utowana." Both gentlemen accompanied the first expedition, but owing to Dr. Fairchild's illness, Mr. Greenway alone collected ants on the second. The collection comprises 22 forms, and though there are no new forms it furnishes two new records (Iridomyrmex pruinosus and Camponotus planatus) for the archipelago.

\section{Ponerinæ}

Odontomachus hæmatoda insularis Guérin var. pallens Wheeler-Wemyss Bight and Bannermantown, S. Eleuthera I. $\Varangle$ (Greenway).

${ }^{1}$ Wheeler, W. M. The Ants of the Bahamas, with a List of the Known West Indian Species. Bull. Amer. Mus. Nat. Hist. 21, 1905, pp. 79-135, 1 pl., 12 figs.

${ }^{2}$ Mann, W. M. Additions to the Ant Fauna of the West Indies and Central America. Bull. Amer. Mus. Nat. Hist. 42, 1920, pp. 403-439, 10 figs. 


\section{Pseudomyrminæ}

Pseudomyrma flavidula F. Smith-One worker from Watlings I. (Greenway).

Pseudomyrma elongata Mayr-One worker from Conception I. (Greenway).

\section{Myrmicinæ}

Pheidole megacephala Fabr.-Grand Bahama I. $24 \varnothing \quad q$ and Watlings I. 24 ६ (Greenway).

Pheidole fallax jelskii Mayr var. antillensis Forel-New

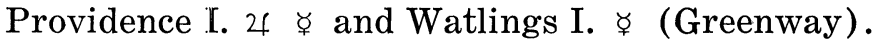

Pheidole flavens Roger-Bannermantown, S. Eleuthera I. (Greenway).

Crematogaster (Orthocrema) steinheili Forel-Bannermantown, S. Eleuthera I. 㝏 (Greenway); Mayaguana I. $\Varangle \quad$, nesting in pods of mahogany (Fairchild).

Crematogaster (Acrocoelia) lucayana Wheeler-Grand Bahama I. ఈ (Greenway).

This form is probably only a variety of $C$. sanguinea Roger of Cuba.

Monomorium carbonarium ebeninum Forel-Watlings I. ఫ্ , New Providence I. $\Varangle$ and Bannermantown, S. Eleuthera I. $\lcm{\text { }}$ (Greenway).

Solenopsis geminata Fabr.-Great Inagua I. ৮̧, Watlings I. $\Varangle$, New Providence I. $\Varangle$, Crooked I. $\Varangle$ and Clarence Harbor, Long I. $\Varangle \quad$ (Greenway); Conception I. $\Varangle \quad$ (Fairchild and Greenway). The typical black West Indian form of the species.

Cyphomyrmex rimosus minutus Mayr-Crooked I. ఫ (Greenway).

\section{Dolichoderinæ}

Iridomyrmex pruinosus Roger-Mayaguana I. $\Varangle$ (Greenway). Common in Cuba and Florida but not previously recorded from the Bahamas.

Dorymyrmex pyramicus Roger-Nassau, New Providence I. $\succ$, Crooked I. $\succ$ and Cat I. $\Varangle$ (Greenway).

These workers are intermediate in color between the typical form of the species and the following variety.

Dorymyrmex pyramicus var. niger Pergande-Goat Cays $\Varangle$, 
Crooked I. $\Varangle$, East Plana Cay $\Varangle$ and Conception I. $\Varangle$ (Fairchild) ; Watlings I. $\Varangle$, Mayaguana I. $\Varangle$ and Rum Cay ६ (Greenway).

\section{Formicinæ}

Brachymyrmex heeri Forel-Two workers from Cat I. ఫ (Greenway).

Brachymyrmex heeri var. obscurior Forel-Rum Cay $\Varangle \quad q$

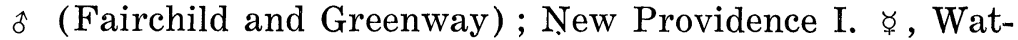
lings I. $\Varangle$, Great Inagua I. $\Varangle$ and Crooked I. $\Varangle$ (Greenway). Camponotus (Tanæmyrmex) conspicuus xqualis RogerNassau, New Providence I. ఈ (Greenway).

Camponotus (Tanæmyrmex) fumidus lucayanus WheelerNassau, New Providence I. $\Varangle$ and Bannermantown, S. Eleuthera I. $\Varangle$ (Greenway).

Camponotus (Tanæmyrmex) ramulorum Wheeler var. marcidus Wheeler-East Plana Cay $\Varangle$, living in dead stems of Cocothrinax (Greenway).

Camponotus (Colobopsis) triton Wheeler-I have recently described this species (Bull. Mus. Comp. Zool. 77, 1934) from a single female specimen taken by Dr. W. M. Mann at Fresh Creek, Andros I.

Camponotus (Myrmobrachys) planatus Roger-A single small worker from Grand Bahama I. (Greenway).

Not previously recorded from the Bahamas though common in Cuba and Southern Florida.

Paratrechina longicornis Latr.-New Providence I. $\nsucceq$, Great Inagua I. $\nsucceq$, Abaco I. $\forall$, Rum Cay $\nsucceq$, Crooked I. $\nsucceq q$, Watlings I. $q$ q and Bannermantown, S. Eleuthera $\Varangle$ (Greenway).

Nylanderia steinheili Forel-Cat. I. $\Varangle \quad \circ$ (Fairchild). 

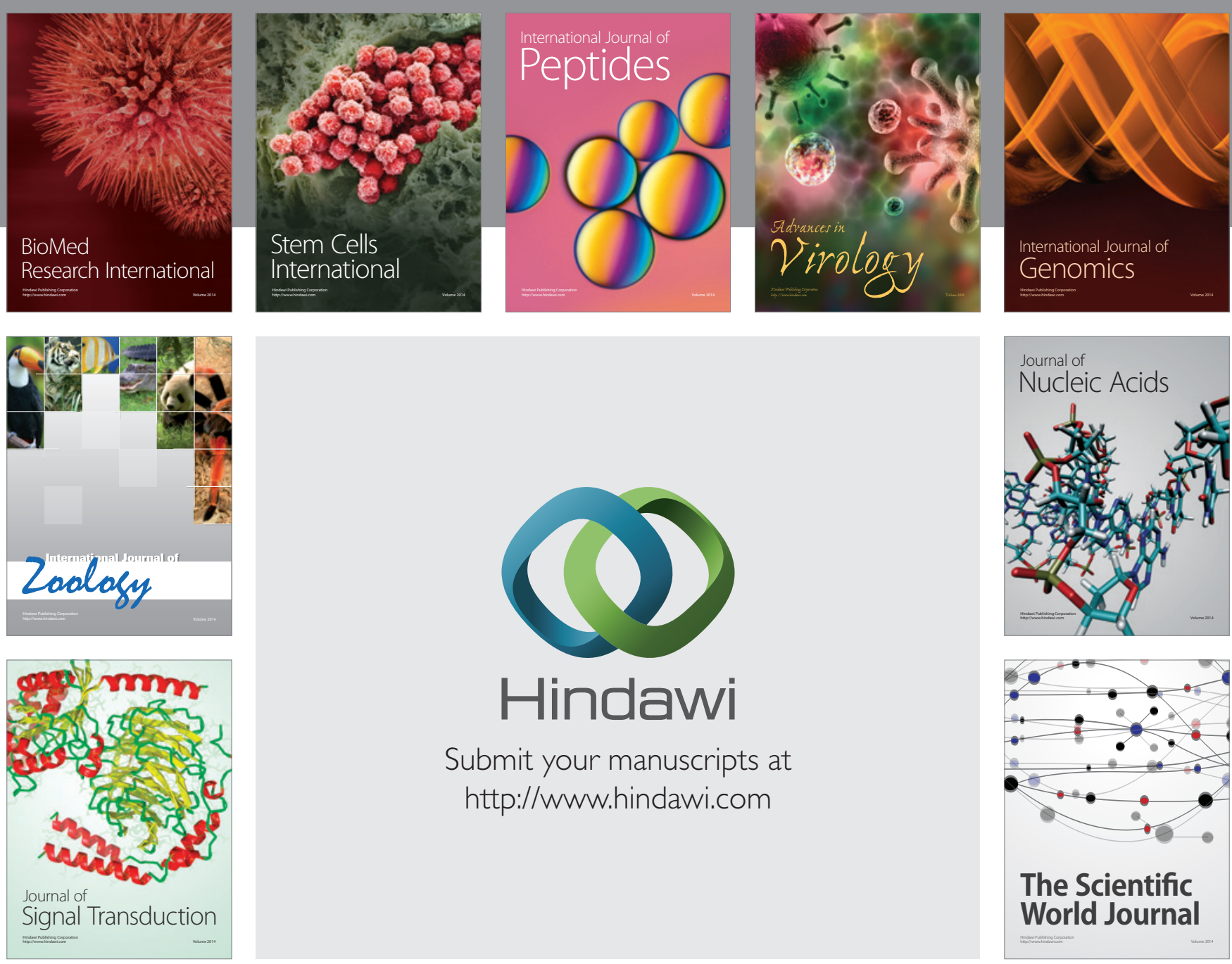

Submit your manuscripts at

http://www.hindawi.com
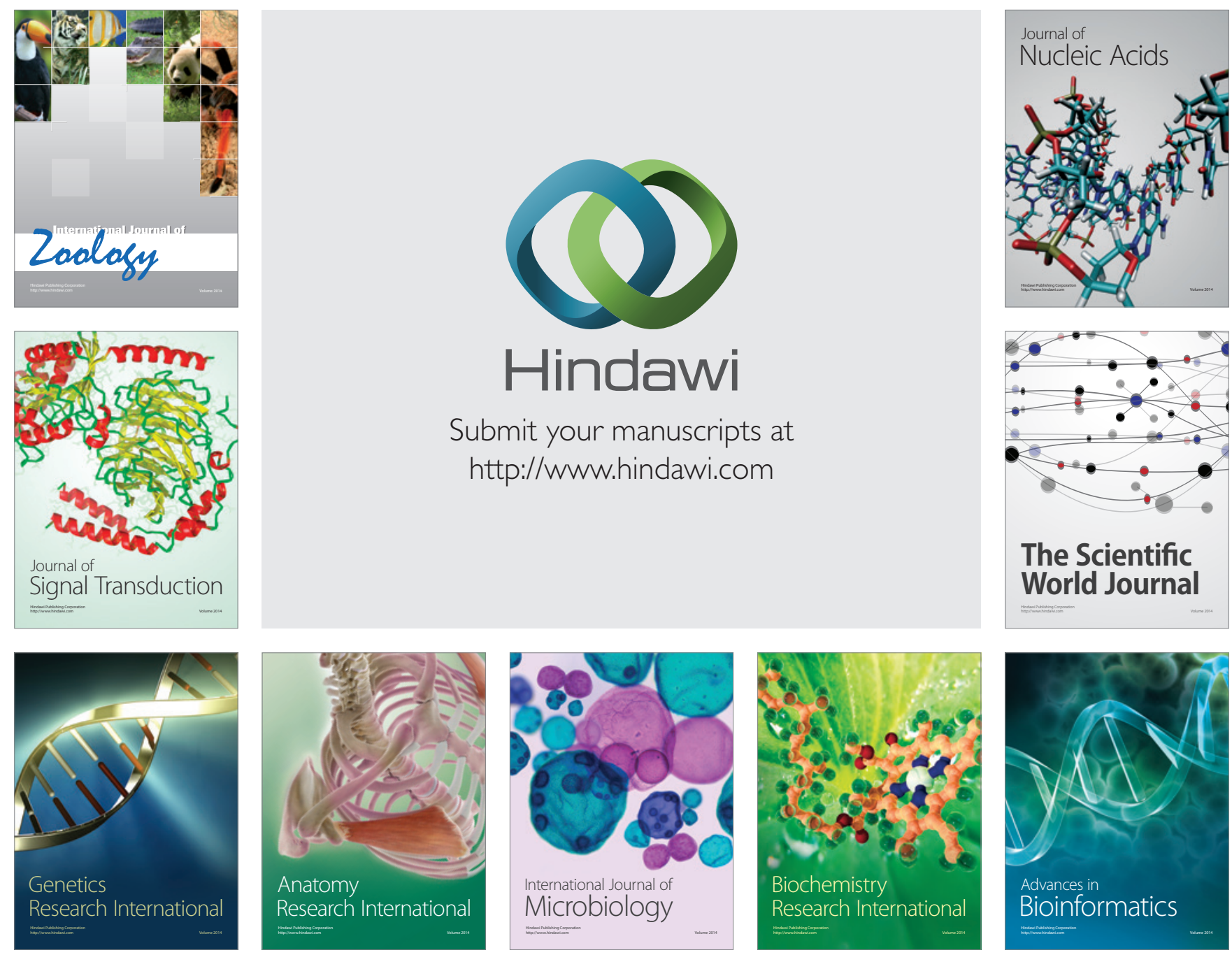

The Scientific World Journal
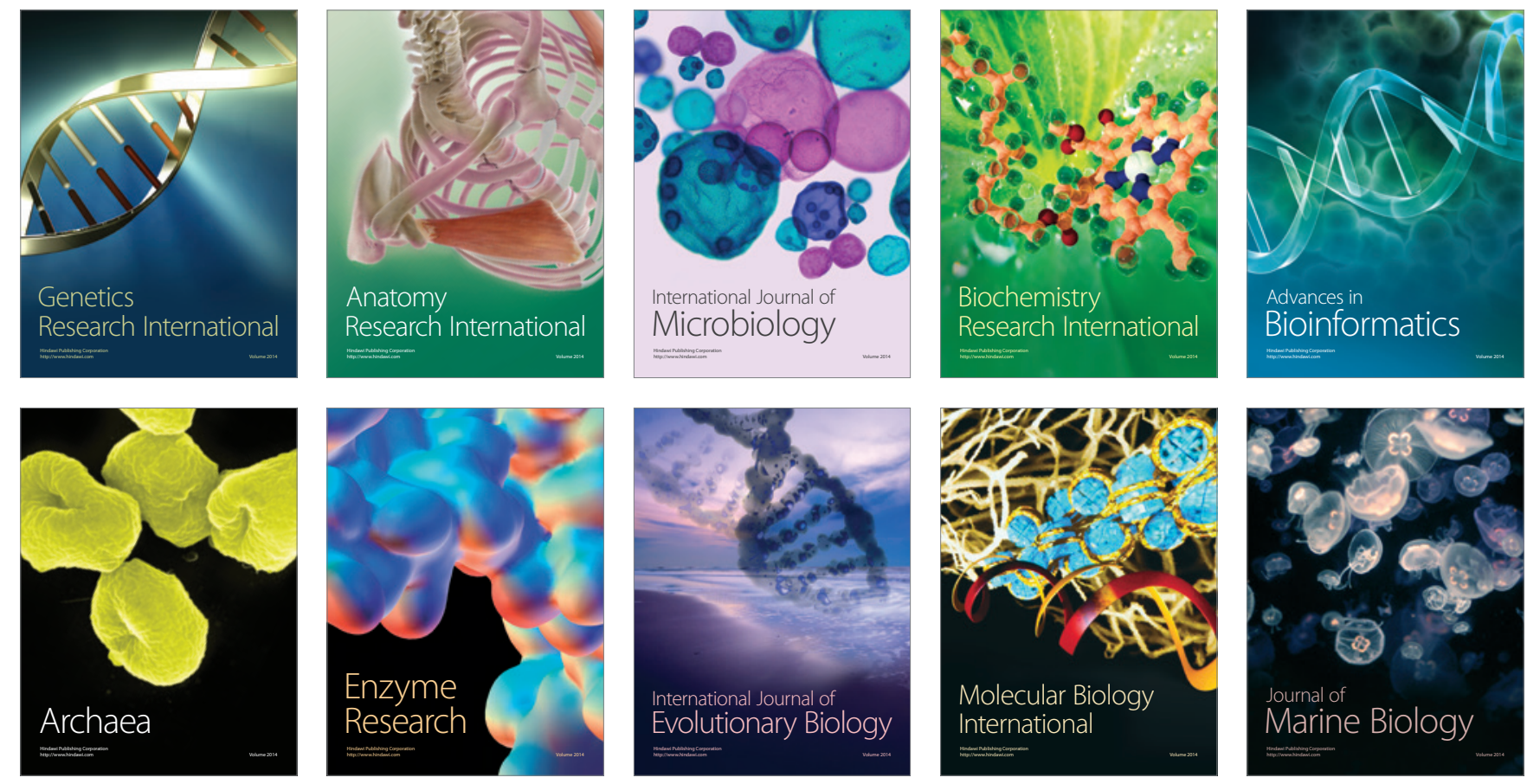